\title{
Canon, criterion and circularity: An analysis of the epistemology of canonical theism
}

\begin{abstract}
Author:
Daniel J. Pratt

Morris-Chapman ${ }^{1}$ (D)

Affiliation:

${ }^{1}$ Department of Church History and Church Polity,

Faculty of Theology and Religion, University of

Pretoria, South Africa
\end{abstract}

Research Project Registration: Project Leader: G.A. Duncan (1) Project Number: 02618958

\section{Description:}

This research is part of the research project, 'History of Theological Education in Africa' directed by Prof. Dr Graham Duncan of the Department of Church History and Church Polity at the Faculty of Theology, University of Pretoria.

Corresponding author: Daniel Morris-Chapman, danielmorrischapman@ yahoo.co.uk

\section{Dates:}

Received: 09 Apr. 2018

Accepted: 29 June 2018

Published: 20 Nov. 2018

How to cite this article: Pratt Morris-Chapman, D.J., 2018, 'Canon, criterion and circularity: An analysis of the epistemology of canonical theism', HTS Teologiese Studies/Theological Studies 74(1), a5022. https://doi. org/10.4102/hts.v74i1.5022

\section{Copyright:}

(c) 2018. The Authors. Licensee: AOSIS. This work is licensed under the Creative Commons Attribution License.

\section{Read online:}

Scan this QR code with your smart phone or mobile device to read online.
In recent years, William J. Abraham has suggested the creation of a new subdiscipline for examining the epistemology of theology. This article provides an overview of this proposal, highlighting some of the philosophical concepts, such as 'Aristotelian epistemic fit' and particularism, that Abraham drew upon when formulating this approach. It then proceeds to an examination of Abraham's application of these ideas to his preferred theological scheme, canonical theism. Limitations and challenges to Abraham's position are discussed as well as ways in which weaknesses in his approach might be addressed.

\section{Introduction}

Over the last decade William J. Abraham has argued repeatedly concerning the need for the creation of a new subdiscipline entitled the 'epistemology of theology' to explore what constitutes 'appropriate' epistemological evaluation in theology. He writes:

It has been commonplace in epistemology ... to explore in detail the epistemology of particular academic disciplines. The epistemology of science, for example, has received the lion's share of interest; but attention has also been given to mathematics, history, aesthetics, and ethics. The crucial warrant for these later developments goes back to Aristotle's insistence ... [that] we should fit our epistemic evaluations in an appropriate way to the subject matter under investigation. (Abraham \& Aquino 2017:1)

Following Aristotle (2000:5), Abraham argues that in exploring the epistemology of any discipline it is important to allow the subject matter, in this case theology, to shape the kind of considerations that 'should be brought to bear on the rationality of the issue under review' (2006:29). Hence, if one begins with a commitment to theism, it is important to assess the rationality of its claims in an appropriate manner - allowing particular features of the subject to affect the way in which it is measured. ${ }^{1}$ Hence, Abraham considers that to engage in the epistemology of theology is: (1) to begin with a robust vision of theism and (2) to assess the rationality of this vision of theism retrospectively in an appropriate manner.

Abraham's approach to the epistemology of religious belief is distinctive because it is the reverse of that taken by many other scholars in this field. ${ }^{2}$ Whereas the standard strategy has been firstly to develop a general theory of rationality and justification before applying this to theism, Abraham begins instead with theism - turning the epistemology of religious belief on its head. ${ }^{3}$ However, while his work has inspired a number of historical studies, ${ }^{4}$ his overall account of the epistemology of theology is yet to receive the detailed attention it deserves. ${ }^{5}$ Despite this, a small number of articles, the majority being book reviews that treat individual works in isolation from Abraham's wider corpus, ${ }^{6}$ do engage with his epistemological proposals. While these analyses are typically very brief, several note the potential danger of relativism for Abraham's proposals. For example, in an article entitled 'Notes and Comments', Buckareff suggests that Abraham's commitment to Aristotelian 'epistemic fit and his rejection of a "one-size-fits-all" approach to making epistemic evaluations' implies that he is

1.Abraham's adoption of this Aristotelian principle, 'epistemic fit', underpins his examination of the epistemology of theology. While acknowledging that this differentiates his approach from writers who attempt to locate a generic epistemology for all disciplines (2017:1) he considers that: we do not expect historical claims to be measured by the kinds of arguments that would apply to mathematics or the natural sciences ... in the end each network of beliefs must be taken in its radical particularity. We are thus entitled to work our way outward from the theism on offer, take seriously the kind of epistemic suggestions advanced (2006:45).

2.In taking this approach Abraham's work differs from 'reformed epistemologists' like Plantinga (2000) because the latter begins with a theory of what constitutes warranted belief. For further discussion see Abraham (2006:7-8).

3.For further discussion, see Hick (1966, 1989), Phillips (1981, 1988), Alston (1991), Swinburne (1991), Yandell (1993) and Wolterstorff (1995).

4.For further discussion, see Lindbeck (1999), Webster (2001), Work (2002), Levering (2007) and Treier (2008).

5.For example, while Fiorenza criticises Abraham's discussion of the history of modern theology, she does not engage seriously with his writings and makes no references to his numerous publications (2002).

6.For example, see Grenz (2001), Ford (2006), MacSwain (2008), Smith (2008), Vidu (2009) and Wolterstorff (2011). 
committed to 'some species of epistemic relativism' (2009:85).? While Abraham's response might be that he considers theologians should 'resist the temptation to develop a general epistemology,' arguing that if 'historians and natural scientists' are permitted to assume a network of 'epistemic platitudes' (i.e. the reliability of our senses, etc.) then theologians should be granted the same freedom (2006:28-29), Wolterstorff points out that these 'so-called' platitudes by 'no means function as platitudes in the field of epistemology' and are 'highly controversial epistemological positions' (2011:104). Moreover, Buckareff observes that if different religious traditions are permitted to insulate their beliefs from proper 'epistemic scrutiny', extreme theological statements could become impervious to disconfirmation (2011:88). ${ }^{8}$ While expressing a similar concern, Smith wonders whether Abraham might be able to mitigate against this difficulty if, in addition to his use of epistemic fit, he added principles such as 'consistency' and 'coherence' (2007:141).

I will not seek to offer an argument either for or against epistemic relativism here. ${ }^{9}$ Neither will I offer a critique of Abraham's overall methodology. My objective is rather to explore the internal logic of his work. For this reason, I will critically assess his application of the principle of Aristotelian epistemic fit to his preferred vision of theology, canonical theism, in order to determine the coherence of his own specific account of the epistemology of theology. To my knowledge a detailed discussion of this kind, attending to Abraham's wider corpus, is yet to be provided. However, to accomplish this, it will firstly be necessary to introduce both (1) Abraham's vision of theism and (2) his account of its justification.

\section{Abraham's theological vision}

In his early publications Abraham, a Methodist, ${ }^{10}$ regularly identifies himself with the evangelical tradition - frequently highlighting the importance of scripture (1981:32). ${ }^{11}$ However, his later works consider the Protestant emphasis on scripture to be a distortion (2005a:16-18) ) $^{12}$ that has diminished the rich canonical heritage of the church, accommodating only those elements that have a clear basis in the Bible. ${ }^{13}$ Abraham

7. In a similar vein, Lamberth points out that 'simply claiming epistemic priority' does not connect faith to reality and indicates the need for Abraham to demonstrate the truth of theological claims more objectively (2002:276).

8. Alston's work Perceiving God could be of use here. He suggests that one way to deal with contradictory truth claims - such as when claims to revelation (mystical perception) conflict with ordinary sense perception - is to allow the more established belief-forming practice (SP) to have the casting vote (1991:173).

9. My understanding is that theologians are in a similar predicament to everyone else when it comes to locating objective ways for determining the accuracy of their beliefs. For further discussion see Alston (1993:115-119).

10.In this essay, when the term 'Methodist' is used with a capital $M$ it refers to the Methodist Church (a denomination founded by John Wesley). When it is used with a lowercase $m$ it refers to an epistemological position.

11.For example, in The Divine Inspiration of Holy Scripture he acknowledges that his position is a continuation of the evangelical tradition (Abraham 1981:11) and in Divine Revelation and the Limits of Historical Criticism he states that his work should be viewed as a deliberate contribution to the evangelical tradition as it is expressed in the thought of John Wesley (Abraham 1982:5).

12.For example, in an article entitled 'Saving Souls in the Twenty-First Century', Abraham comes to the conclusion that the 'biblicism' upheld by figures such as Wesley has devastated the church (2003:19).

13. He writes: 'the propositions of scripture became the premises of a deductive science secured as true by the fact that they were spoken by God. All the teaching of the church were taken as derivable from scripture' (2010b:695). concludes that after the schism between East and West (1054 $\mathrm{AD})$ the church's conception of canon changed to that of criterion. ${ }^{14}$ Abraham maintains that, while previously canons were understood as a means of grace through which people were initiated into the life of the church, over time the Bible has come to be viewed as an epistemological 'norm for testing all theological proposals' (1998:157-160). ${ }^{15}$ He considers that this move has rendered vital parts of the Christian faith redundant (2006:113). ${ }^{16}$

Abraham's theological vision, canonical theism, ${ }^{17}$ is about accepting the entire canonical heritage of the early church. ${ }^{18}$ In order to bring about renewal, ${ }^{19}$ Abraham believes that it is necessary for the church to recover the original understanding of canon - a list of materials identified as being vital for Christian initiation $(1998: 14-15,26)$ - to broaden its attention from an excessive focus on scripture in order for it to be enriched by the canonical heritage of the undivided church of antiquity. ${ }^{20}$ He argues that, prior to the great schism (1054 AD) ${ }^{21}$ the early church identified a broad catalogue of material, including rites of passage such as baptism, liturgical traditions, iconographic material, ecclesiastical regulations, persons (such as the fathers, saints and teachers), creeds and so on (1998:37-38). Abraham emphasises that these 'canons' were not created to be epistemological criteria. ${ }^{22}$ On the contrary, he argues that in recognising certain materials as 'canons' the church judged them to be the means of grace necessary for immersing new believers into the life of faith $(1998: 53,112,2006: 16){ }^{23}$

14.Abraham is highly critical of the Catholic Church and targets Aquinas as initiating this shift. This has led to several criticisms, with commentators questioning whether or not Aquinas did in fact mark this transition (Levering 2007). For example, Long questions why Aquinas is so 'readily rejected' by Abraham and argues that the 'true culprit in the Western tradition' is 'Locke who turned miracles into positivist evidence' (2003:78).

15.When researching the Christian evangelisation of the Roman Empire in the late 1980 's Abraham states that he stumbled upon the original understanding of canon - a list of material identified as being helpful for Christian initiation $(1998: 14-15,26)$.

16.Abraham goes as far as to suggest that grounding all doctrine in scripture left Protestants extremely vulnerable to Unitarianism, which he describes as 'a radically conservative movement' that rejected the doctrine of the Trinity because it took sola scriptura to its logical conclusion (2006:113).

17.While Abraham is the architect behind the proposal for a 'canonical theism', he has developed this vision as a collaborative project. Abraham states that " $i] \mathrm{i}$ t is precisely because the ideas pursued are beyond the work of any one scholar ... that he has recently enlisted the help of others (2008:xvii).

18.Abraham (2001) states that his: 'central thesis is relatively simple ...We should expand the material identification of canon to take in more than scripture, so it can cover the whole canonical heritage of the early church' (p. 238)

19. His proposal for a canonical theism is a proposal for renewal. For further discussion on this point see his Logic of Renewal (2003b).

20.He writes: 'The church possesses not just a canon of books in its Bible but also a canon of doctrine, a canon of saints, a canon of church fathers, a canon of theologians, a canon of liturgy, a canon of bishops, a canon of councils, a canon of ecclesial regulations, a canon of icons, and the like ... Canonical theism is the theism expressed in and through the canonical heritage of the church' (2008:2).

21 Another problem, which will not be discussed here, is whether or not this particular schism marks the turning point from canon to criterion or whether this shift can be dated earlier.

22.According to Abraham, the primitive church was not seeking to delineate theological criterion but 'was interested primarily in singling out medicine for the soul' (1998:156). He writes: 'The Creed is exceptionally useful in catechetical work; the Scriptures are useful in providing agreed texts for preaching; the Eucharist is pivotal in nurturing an intimate communion with the risen Lord the writings of the fathers are invaluable in pursuing the implications of the scriptural material (1998:53).

23.Abraham writes: 'The sacraments, the scriptures, the creed, the canon of the fathers, and the like .... were construed as materials and practices which fed the
soul, which mediated the life of God, which returned human beings to their true destiny ... medicine to heal the sickness of the world' (1998:112). 
While Abraham's distinction between the church's canonical heritage and epistemic criteria has been generally well received, Treier (2008) argues that more historical research into the early church's conception of the word 'canon' needs to be undertaken. A number of other commentators, objecting to Abraham's construal of various historical figures, have also disputed when the meaning of canon changed. ${ }^{24}$ For example, while Webster is largely supportive of Abraham's soteriological conception of the canonical heritage he objects to Abraham's depiction of the Reformers (2001:233-234). In response to these criticisms, Abraham has acknowledged that there are historical oversights in his work (2001:239) and has stated that he wholeheartedly welcomes detailed 'historical inquiry into the origins, content, and meaning of the canonical heritage of the Church' (1998:xii).

Other commentators, including Fout (2008:394) and Smith (2008:359), have expressed doubts about Abraham's suggestion that this form of theism remains 'alive and well'. While no ecclesial body formally upholds only the canonical heritage of the early church, Abraham considers that 'countless simple believers' have 'across space and time' upheld this vision of theism (2006:14). This fascinating claim will be addressed in detail later; needless to say it is far from clear to whom, or to which church, Abraham is referring here. Nevertheless, having now introduced Abraham's vision of theism, a canonical theism that has not been cut back to favour a particular epistemology (2006:14), the remainder of this essay will explore his account of the epistemology of canonical theism. For clarity, it is helpful at this juncture to list the main points under discussion:

1. Abraham begins by presupposing a theological vision: canonical theism.

a. Canonical theism consists of the canonical decisions of the early church up until $1054 \mathrm{AD}$.

$i$. Is there a church in existence that only upholds these canons?

2. Having identified a theological vision, he explores its implicit epistemological proposals.

a. The main reason offered in defence of canonical theism is an appeal to revelation. Theological beliefs are thus justified by an experience of divine revelation.

$i$. How is divine revelation received?

3. Revelation is mediated through the church's canonical heritage to members of the church.

a. Those initiated into the life of the church receive this revelation.

$i$. Which church upholds these canons? How does one join it?

4. Adherents believe in canonical theism because they receive revelation via the church's canonical heritage.

a. The canons (which constitute canonical theism) bring about belief in canonical theism.

i. Is canonical theism justified by canonical theism?

\section{The epistemology of theology: Canonical theism}

Earlier we noted Abraham's contention that, before engaging with epistemology, theologians need to be clear about the content of the faith that they wish to articulate. Put simply, he considers that the vision of theism has to be secure from the start. Abraham acknowledges that this approach to epistemology resonates with the 'particularism' proposed by Roderick Chisholm (2006:30). ${ }^{25}$ Like Chisholm, Abraham considers that we should not begin epistemology with a criterion; we should instead (1) begin with what we think we know and then (2) work out the rationality of our beliefs retrospectively using the principle of Aristotelian epistemic fit. ${ }^{26}$ In this case the particular claims to knowledge are those contained in the vision of God found within the canonical heritage of the early church. Thus, Abraham's particularist orientation first necessitates that (1) canonical theism, as an entity constituting a network of propositions, be accepted in its entirety (2006:43). ${ }^{27}$ Next, it requires Abraham to (2) uncover a hidden 'logic' governing this brand of theism, to make explicit the implicit epistemological proposals that lie below its surface (2006:51). In sum, Abraham's epistemological orientation requires him to make explicit the implicit reasons advanced by the church, and indeed by the ordinary believer, for the existence of their faith.

Abraham argues that one of the key 'epistemic suggestions' that naturally lies 'below the surface of canonical theism' is an appeal to divine revelation (2006:51). He considers this to be the main reason offered for the existence of faith - for both ordinary believers and the church generally. Abraham (2006) writes:

... at the core of the faith, as seen from an epistemic point of view, there is a special divine revelation that comes to us from without and brings the truth about God and ourselves to burning focus. This ... has been central in the testimony of believers as to why they believe as they do. Crucial to the truth of canonical theism is the claim that God has acted in history to disclose ... his nature ... because of these we are warranted in accepting very robust claims about his character and intentions. (p. 56)

Here Abraham makes two assertions: the first is that central to the testimony of many believers is that their warrant for believing in God is in some kind of appeal to divine revelation. This revelation somehow convinces them of the truth about who God is. It therefore becomes the primary reason that people accept canonical theism. The second assertion is that crucial to the truth about canonical theism is its claim that God has acted in history to reveal himself. Thus, at the basis of an individual's commitment to canonical theism is an appeal to divine revelation, and at the basis of the canonical heritage's claims to know the truth about God is an appeal to divine revelation.

25.A helpful summary of this position is offered by Chisholm's doctoral student, Prof Ernest Sosa (1991): 'Which should come first: a method or set of criteria for Ernest Sosa (1991): 'Which should come first: a method or set of criteria for
determining when we have a bit of knowledge, or particular examples of knowledge, in terms of which we can determine criteria? Those who give preeminence to method of criteria may be called methodists, and those who give pre-eminence to particular examples (e.g., my knowledge that I have two hands) may be called particularists ... Locke and Hume were methodists; and Reid and Moore particularists' (p. 158). In this context the term 'methodist' should not be confused with the Methodist church.

26. Chisholm writes: 'In formulating such principles we will simply proceed as Aristotle did ... As "particularists" ... we will fit our rules to the cases ... Knowing what we do about ourselves and the world, we have at our disposal certain instances that our rules or principles should countenance, and certain other instances that our rules or principles should rule out or forbid' (1973:35).

27. He begins the task of epistemology with his vision of theism intact. He then takes his time to explore 'what kinds of considerations apply when we are exploring the justification of canonical theism' (2006:35). 
Hence Abraham argues that individuals become convinced of the truth of canonical theism through an experience of divine revelation. Therefore, if he can articulate how individuals appropriate divine revelation he can unearth reasons for why he thinks canonical theism to be justified. Essentially, Abraham argues that in 'their own special way' it is the church's canons that 'mediate divine revelation' (2006:110). Thus, it is through the canonical heritage that people are connected to God:

The scriptural material is both formally and informally divided so as to construe it fundamentally as giving access to God's saving activity in Jesus Christ ... In turn, the central sacraments, baptism and Eucharist, clearly involve a recapitulation of the death and resurrection of Jesus Christ, first in the life of the convert and then in the regular worship of the community. Properly used [these canons] are meant to connect the Christian disciple not just to the story of Jesus but to the risen Lord present mysteriously through the working of the Holy Spirit. (1998:57-58)

This citation implies that it is the canonical heritage that 'connects' individuals to God by mediating divine revelation to them. ${ }^{28}$ Therefore it would seem that, in the first place, it is in receiving the church's canonical materials that an individual can appropriate divine revelation. ${ }^{29}$ However, the question remains, how is it that an individual appropriates revelation through the canons; how exactly are the canons of the church linked to divine revelation?

Abraham argues that the church as a collection of people has a corporate sense (oculus contemplationis) of the revelation of God (2006:108). ${ }^{30}$ However, Abraham registers the limitations of this spiritual eye. ${ }^{31}$ He stresses, for example, that it is not possible to go straight from the 'inner witness of the Holy Spirit to the doctrine of the Trinity' (2006:97). He argues that because human beings cannot take in the magnitude of God's revelation all at once, doctrines take time to develop. ${ }^{32}$ He maintains that this period is needed for the church to contemplate worshipfully and theologically the divine revelation it has received. Doctrines do not emerge straightaway but can take centuries to come into view (2006:102, 105).

Abraham's decision to privilege the canonical life of the church prior to 1054 implies that revelation is (in some sense)

28.Abraham clarifies that it was in his work The Logic of Evangelism (where he undertook an analysis of the evangelisation of the Roman Empire) that he undertook an analysis of the evangelisation of the Roman Empire) that he stumbled upon what he now terms 'canonical theism'. Abraham considers that it was here that he came across the pivotal role of the early creeds for understandin love the God identified in the rich canonical heritage of the church' (2006:xii-xiii).

29. He writes:' the church developed diverse internal canons to be used to initiate its members into the life of God made manifest in Jesus Christ. These canons were seen as derived from the work of the Holy Spirit, hence were gifts of the Spirit, and they were to be accepted and used in a manner appropriate to such sacred gifts (1998:57). On this view the canons of the church are a treasure of materials that have been accepted by the church to initiate people into the canonical faith of the church.

30.This corporate spiritual sense organ is comparable to what John Henry Newman referred to in the Rambler (1859a) as the sensus fidelium or 'sense of the faithful' (1859b:198-230).

31. Here Abraham differs from Plantinga, who argues that our spiritual senses can help us to obtain a robust form of theism (Plantinga 2000:334).

32. His understanding is comparable to, but different from, John Henry Newman's discussion of the development of ideas (1845) ongoing - at the very least until the schism between East and West (2006:105). While Abraham stresses that divine revelation is definitively given in Christ, that there is no ongoing revelation on a par with the incarnation, he states that the canonical heritage is created by the accumulated effects of divine revelation upon the church over time (2006:49, 106-107). Abraham (2006) explains that:

From the beginning, special revelation in Israel created a very special people. The soteriological intention embedded in Israel worked itself out in the formation of a community with a long history that culminated in the renewal of Israel in and through the life, death, and resurrection of Jesus of Nazareth ... It was within this community that the extra special revelation made through Jesus of Nazareth was effected, recognized and received. It was in the community created by Jesus that this revelation was treasured, recorded preached, mulled over, and transmitted across the generations ... [Here] There is an ordered progression of divine revelation in Israel and in the church that operates as pivotal data in the very particular vision of God that emerges over time. (p. 105)

Hence he believes that the church's canons arose out of the deep interaction of the special revelation of God. He acknowledges that because the canonical heritage takes time to emerge it is difficult to be precise concerning the nature of the connection between divine revelation and the doctrines of the church. He writes: 'no matter how we explain the relationship' there is always 'a significant gap between the vision of revelation embraced and the doctrines adopted' (2006:102). However, Abraham (2006) states that:

If we must work with ... summary statements, we might say that the doctrine of the Trinity arose over time out of the deep interaction of the special revelation of God in Israel, the extra special revelation of God in Jesus Christ, experience of God in the Holy Spirit, and sanctified creative imagination and reason. (p. 106)

Thus Abraham concedes that the relationship between revelation and the canonical heritage is 'multidimensional, informal, and indirect' (2006:106). On this understanding the canonical heritage is given to the church over time by the Holy Spirit for the purpose of bringing people to God. Abraham considers that in 'their own special way' the canons 'mediate divine revelation' because of a complex interaction between revelation and the church (2006:110). Thus, in one's reception of the church's canonical heritage, one somehow appropriates divine revelation. In sum, the canons 'given to us by God' are what 'initiate us into divine life' (1998:53).

\section{Is canonical theism 'paper religion'?}

From this summary of Abraham's position it is apparent that he holds the church's rich canonical heritage to be the result of an accumulation of revelation over the centuries. On this understanding, the church has been some kind of vessel for divine revelation. The initiated, those who receive the canons of the church, are initiated into the life of God and are connected to divine revelation. However, given that Abraham has a tendency to link the appropriation of revelation to the initiation into a concrete ecclesial body there is an unresolved 
question here: which church does one need to join? Which church does he believe that the revelation of God has interacted with over time? While he states that canonical theism relates to the canons approved before the great schism, (2006:14-15) one would need some sort of time machine in order to be initiated into that particular church. Despite this, in a number of places, Abraham (1984) states that:

... to join the body of Christ, one cannot avoid joining some concrete, particular body of believers at some particular place in space and time. To claim that one belongs to the church universal but that this doesn't entail belonging to some specific body of believers is a sham ... one cannot join the Christian community without being involved in some particular Christian community. These particular Christian communities are not just physical entities of brick and mortar; they are expressions of Christian tradition. (pp. 3-4)

Elsewhere, Abraham (2002) is adamant that God's grace is mediated through a real concrete ecclesial community:

Grace does not ... [work] in a vacuum. God is free to work as and how he pleases, yet he has covenanted to work in and through baptism, through the Eucharist, through fellowship ... and so on. To omit these from initiation is to treat grace as unrelated to the concrete, physical character of our existence ... initiation is [thus] intrinsically related to physical incorporation into the church through baptism ... (p. 130)

\section{Abraham (2002) also states that:}

God in his reign has established his eschatological community. It is therefore incoherent to say that one can enter that reign but remain outside the church. Baptism is inescapable and essential, once one grasps this point, for it is through baptism that one enters the Israel of God, that body where God reigns supreme in worship and praise. (p. 130)

Here it seems Abraham's understanding is that the appropriation of divine revelation relates to a 'concrete initiation into the flesh and blood of the Christian community' (2002:128-129). Thus, it would seem his concept of the way in which revelation interacts with the church is also linked to the idea of a definite physical community. That is, Abraham's concept of the church as a carrier of revelation is one that appears to require a real ecclesiological root. ${ }^{33}$ This would imply that the ecclesiological vacuum in Abraham's account poses a more serious epistemological problem. This makes questions about his ecclesiological inclinations pertinent to the present enquiry.

Abraham does acknowledge that his vision of canonical theism might appear 'untidy' (2006:15); however, he does not seem to resolve the implications raised by his contention that the church is a carrier of revelation. Abraham does state that 'the eastern wing of the church during and after the schism

33 Reflecting on Symeon the New Theologian's work, Abraham does pose the question as to whether or not holy 'lay monks' might be able to mediate 'entry into
the kingdom of God' - the point being, if the church became corrupt, could a person be initiated into the life of God by a lay monk? He acknowledges that 'these person be initiated into the life of God by a lay monk? He acknowledges that 'these (2017c:136-137). Nevertheless, while this might suggest that his views on the appropriation of revelation and initiation have mellowed over time, it is not clear whether or not he affirms Symeon's position - or how he might incorporate it into whether or not he affirms Symeon's position - or how he
his account of the epistemology of canonical theism.
...' has maintained the canonical heritage 'in keeping with the canonical vision of the early church' (1998:113-114). If Abraham modified his conception of revelation, ${ }^{34}$ and became a member of the Orthodox Church, he could perhaps argue that the canonical heritage of the Orthodox Church is justified by the mediation of the revelation of God through that physical institution. However, despite his apparent inclination toward the Orthodox Church, Abraham remains a member of the American United Methodist Church, which by his own admission (1995) is far from upholding only the canons held 'prior to the great schism' between East and West. $^{35}$

An alternative solution to this problem would be for Abraham to revisit his assessment of Roman Catholicism. ${ }^{36}$ Several commentators are highly critical of Abraham's rendition of a number of Catholic figures and it is clear that there are problems with his account. For example, his depiction of Aquinas as a biblical foundationalist $\mathrm{t}^{37}$ is criticised by Webster (2001:12) and Levering, who argues that Aquinas' approach to scripture was both soteriological and participatory involving all the 'practices and materials identified by Abraham as the "Canonical Heritage"' (2007:53). Levering also questions Abraham's contention (1998:115) that the Roman Catholic Church has made the papal office into an 'epistemic mechanism' that can be used to arrive at genuine knowledge (Levering 2007:48). While Abraham considers that this 'distortion of the canonical heritage' brought about the first major split between the East and the West (1998:7778), Levering argues that, were Abraham to give more attention to John Henry Newman's conception of papal infallibility, he might salvage a way for 'Roman Catholicism to return to the Canonical heritage that Newman himself deeply explored' (2007:48). ${ }^{38}$

Levering's suggestion is significant because Abraham is an admirer of Newman's philosophical work (2003b:166). In fact Abraham cites Newman's writing as an ideal example of how to explore the underlying logic governing the development of Christian doctrine and describes Newman's account of the logical continuity of Roman Catholic Christianity with the apostolic church as 'felicitous' (Abraham 2010:177-178). This is particularly interesting when it is understood that Newman's analysis applies Aristotle's principle that different disciplines require different levels of

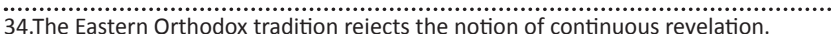

35.The ecclesiological questions arising from Abraham's proposal are not out of place within the wider Methodist context, where there is an attempt to look to other traditions for a more robust ecclesial vision. Abraham's attempt to locate his traditions for a more robust ecclesial vision. Abraham's attempt to locate his
ecclesial identity in the early church is not so strange when this factor is taken into ecclesial identity in the early church is not so strange when this factor is taken into
consideration. For example, a number of Methodist theologians display an consideration. For example, a number of Methodist theologians display an
ambiguity about whether the Methodist Church ought really to be regarded as a ambiguity about whether the Methodist Church ought really to be regarded as a
church at all. Albert Outler, David Chapman, Geoffrey Wainwright and David Carter, among others, consider that the Methodist Church would function better as a religious order within the wider Catholic Church (Watt 2012:119).

36. His conception of revelation would also have to be altered as, like the Eastern Orthodox tradition, Roman Catholicism rejects the notion of continuous revelation.

37. Abraham argues that when Aquinas was 'canonized at Trent' - as 'the doctor of the Church' - Roman Catholicism formally made a foundationalist conception of scripture canonical (1998:108-109).

38. He writes: 'The Roman Catholic tradition involves a deep transposition of the patristic heritage ... the whole effort to canonize epistemological materials in the full and official way taken by Rome is a radical departure from the earlier tradition' (1998:354-355). 
precision to his examination of the evidence supporting the doctrines of the 19th-century Catholic Church (Newman 1845:99). That Abraham considers Newman's examination of the same to be felicitous indicates that he considers Newman to be adept at applying Aristotelian epistemic fit to religious belief. From this it seems that, if Abraham were to revisit his assessment of Roman Catholicism he could develop the ideas found in Newman's essay on the development of doctrine (1845) so as to formulate an account of the implicit logic governing the development of the canonical heritage within the Catholic tradition. Newman's writing frequently applies this Aristotelian concept to various subjects and clearly has the potential to enhance the epistemology of canonical theism at this point. ${ }^{39}$ However, although a move like this could make Abraham's application of the principle of epistemic fit to theology more coherent he is unlikely to take such a step, as he is very critical of Newman's decision to join the Roman Catholic Church (1998:354).

\section{Canonical theism and circularity}

There is another problem with Abraham's analysis. His commitment to particularism and appropriate epistemic fit lead him to explore the reasons adherents have for believing in canonical theism. He states that one of the major reasons given is an appeal to divine revelation. However, he considers that revelation is primarily mediated to individuals by means of the church's canonical heritage in Christian initiation. Therefore, if an individual comes to believe in canonical theism through revelation, as revealed in the canons of the church, then Abraham's proposal is circular. If they believe in canonical theism because they receive revelation through the canons (which constitute canonical theism) then canonical theism is justified by canonical theism. Nevertheless, if Abraham could provide an account of the way in which individuals come to receive revelation aside from their reception of the church's canonical heritage this difficulty could be lessened.

Abraham emphasises that it is through the canonical heritage, the church's means of grace, that individuals come to acquire a rich vision of God. ${ }^{40}$ However, as was noted, he considers humans possess an innate faculty comparable to sense perception that enables them to perceive God's action in the world (2006:48, 66). ${ }^{41}$ Unfortunately, while individuals perceive God through the means of this oculus contemplationis (2006:75-76), Abraham states that this spiritual sense organ has been adversely affected by $\sin .{ }^{42}$ The precise nature of this

\section{For further discussion of Newman in relation to this approach to epistemology, see} Neve (2010:137-166) and Pratt Morris-Chapman (2016:55-67).

40.It is important to acknowledge right at the outset that Abraham considers that even a fully functioning oculus contemplationis can at best take us to belief in God and to initial identification of divine revelation' (2006:97). In and of itself, it cannot bring us to have a robust vision of theism. For this reason it seems individuals primarily come to know and love God through the canonical material; thus any ambiguity in Abraham's work concerning how individuals appropriate divine revelation, aside from this canonical material, is easily accounted for.

41.Abraham understands divine revelation to be the polymorphous action of God in the world (1982:11, 2006:58).

42.A similar perspective is offered by Wainwright, who argues that the evidence for faith 'can accurately be assessed only by men and women who possess the prope moral and spiritual qualifications' (1995:3) problem is unclear. Sometimes he speaks of a 'veil' over the heart, implying that sin impairs our vision of God (2006:59). Other references, however, suggest that it is human inclination that is the barrier to sight. Here, then, revelation is seen but ignored. On this interpretation, sin does not damage our spiritual sense organs but renders us unwilling to attend to what they perceive (2006:64). At other points, Abraham goes as far as to suggest that sin has brought about a 'cognitive malfunction' that presumably would prevent the working of this oculus contemplationis altogether $(2006: 48,111)$. However, this reading would contradict Abraham's claim that human beings have a natural ability to perceive revelation. Abraham does state that 'it is the pure in heart who see God' (2006:187) and affirms that this rehabilitated cognitive state is 'open to all, given certain assumptions about creation and the universal operation of prevenient grace' (2006:76-77). Nevertheless, he does not specify what these assumptions about creation and the universal operation of prevenient grace are. While one might assume his position could be influenced by the Methodist tradition, he is not at all convinced by Wesley's 'assumptions about creation' or his views concerning 'the universal operation of prevenient grace' (2005b:56-58). ${ }^{43}$ All this ambiguity suggests that there is an inconsistency within Abraham's anthropological vision.

Abraham does state that 'a positive response to special divine revelation is akin to crossing a threshold' (2006:95). The idea here is that once one 'crosses over into the world of divine revelation, then revelation will necessarily illuminate every aspect of one's existence'. This in turn has an impact upon 'the cognitive capacities that brought one to divine revelation in the first place' (2006:87-88). Thus, Abraham suggests that the ability of the oculus contemplationis is enhanced when an individual stands on the other side of the threshold of divine revelation. However, while Abraham understands 'crossing the threshold' as a cognitive and spiritual revolution (2006:89), what it is to cross the threshold is not abundantly clear. Though he does say that it is making a positive response to revelation, if humankind are adversely affected by $\sin$, how do they make such a positive response? ${ }^{44}$

Elsewhere Abraham says that crossing the threshold of divine revelation is like 'climbing a mountain', whereby when one reaches the top, he or she sees a panoramic view before him or her, which beforehand was not visible (2006:86). At other times Abraham speaks of this transition as 'stepping inside' an old mansion, which on the outside looks old but within is filled with abundant treasures (2006:119). The nearest Abraham gets to spelling out what exactly crossing the threshold is a narrative about a fictional character named Ms Convert (MC). According to Abraham, before MC had

43.Abraham does nevertheless acknowledge the complexity of these issues and states that much more needs to be done in this area of research (2009:65). Elsewhere he implies that 'in my own Methodist tradition', specifically 'Methodist dogmatic theology in the nineteenth century', there is potentially an answer to dogmatic theology in the nineteenth century', there is potentially an answer to that would need to be addressed if that were our goal' (2017b:193).

44.Abraham's recent work surveys the writings of several theologians (Augustine, Calvin, etc.) who discuss these questions (2017c:21, 45, 94-97, 110, 115-116, 188, 212). However, the manner in which he might seek to incorporate some of these ideas into his own account of epistemology of canonical theism is not discussed. 
crossed the threshold of divine revelation, she believed in God; she had a strong sense of God acting in her life and saw God's creation as a testimony to God's existence. In addition to this, before MC had crossed the threshold of revelation she was also involved in the church community, where the lives of the Christians both encouraged and challenged MC to go on in her spiritual journey. She also read Christian literature about the mystics and engaged with the classical arguments for God's existence. Before crossing the threshold of revelation MC perceived God as speaking to her when she read the Bible. Then one day MC woke up and 'discovered she was a believer'. Soon after this she became baptised (117-119). This narrative suggests that before MC had crossed the threshold of divine revelation she had nevertheless made a positive response to revelation. Abraham states that making such a positive response to revelation is akin to crossing the threshold, yet MC seems to be making a very positive response to revelation before she has crossed the threshold. Abraham does acknowledge that he has used this evasive passive to describe a transition in [MC's] intellectual journey that is difficult to capture' (2006:119). However, if MC had already made a positive response to revelation before she had crossed the threshold of divine revelation, then what is the significance of crossing the threshold of divine revelation?

Abraham (2006) does proceed to tell another story about MC, which presumably has the purpose of revealing what 'crossing the threshold' is. He writes:

She sometimes thought of [her conversion] as having lingered on the porch of a wonderful old mansion she had only wistfully observed from afar, before suddenly stepping inside and entering the vast rooms and winding stairways ... the owner of the mansion [God] had come down himself to welcome her as she entered, to escort her to her own very specially prepared room ... give her ... luminous candles to find her way around ... sometimes he whispered in her ear in a way that cut right to her heart but that left her to mull things over rather than reach for the obvious inference ... portraits of ancient occupants and treasured leaders ... helped her get orientated ... In her initial tour of the building the owner made available to her some of the original plans and identified the names of the great architects who had helped to develop it. He even appointed contemporary guides so she could get her bearings and begin to work through the consequences of her decision. (pp. 119-121)

So Abraham compares crossing the threshold of divine revelation to entering a mansion. The imagery in this story seems to represent key elements of divine revelation, so presumably the porch of this old mansion is the threshold of divine revelation, the owner of the mansion is God, the portraits are the saints, the 'original plans of the building' the scriptures and so on. However, any attempt to ascertain from this story what exactly the 'crossing' element of 'crossing the threshold of divine revelation' is will be left quite in the dark.

Abraham (2006) does say in his story that 'crossing the threshold' cannot be captured or defined by a mere 'decision' to cross the threshold. He writes:

... the language of decision was much too weak. It failed to register the pull of the older ... world on the other side of the porch ... speaking of the change as one due to her decision did not begin to note the fear and trembling or the attraction and dread that came over her during her conversion. Such language did not ... [capture] the agony involved in giving up old ways of thinking and acting ... Nor did it do justice to the thrill of trying out a whole new identity ... There was a personal death and yet resurrection ... There was a horror at how blind and stupid she had been and yet a delight at the mercy and compassion that immersed her very being; there was a total loss of words to describe her experience ... Water had been turned into wine, she knew not how, but the taste and smell were exhilarating ... In the end she crossed the threshold of divine revelation and found herself in a whole new world ... (pp. 120-121)

This suggests that Abraham is uncomfortable about defining what making a positive response to revelation is, because he wants such a process to remain mysterious and awe filled. This aversion to delineating the precise nature of the appropriation of revelation is briefly suggested at other points in Abraham's work (2003a:18-21). However, regardless of his possible aversion to clarifying the mysterious, there are other inconsistencies in Abraham's account of how revelation is appropriated.

These are heightened in an account by Abraham of the stages of faith '.. on the other side of the threshold of divine revelation' (2006:177). Abraham states that once one has crossed the threshold of divine revelation, there are stages of belief. Abraham goes through these stages, which range from the nominal believer, the ignorant believer, the normal believer, through the mature believer and so on. What is of particular interest here is his account of the nominal believer. Abraham (2006) states that the nominal believer is:

The person [who] holds to the faith of the church, but for all intents and purposes refuses to act on it or to let it make any difference to her basic orientation in life. She may well exhibit a readiness to take part in the liturgical life of the church and to make use of the rights of passage ... but her fundamental orientation is one of intellectual indifference; the basic direction and intention is to allow the faith of the church to lie idle. Sometimes this disposition is accompanied by real resistance to the faith; at other times this indifference flows toward real faith. Whatever the ebb and flow, the prevailing cognitive state is one of minimal inward commitment. (pp. 131-132)

The interesting thing to note is that the nominal believer has, according to Abraham, crossed the threshold of divine revelation and yet remains relatively indifferent toward the faith, letting it lie idle within them. This stands in contrast to Abraham's account of MC, who, before she had crossed the threshold of divine revelation, was engaged in the church, Christian literature, the Bible, the classical arguments for the existence of God and so on. Furthermore, the only thing the nominal believer seems to have, on the other side of the threshold, that MC does not is that the nominal believer exhibits a 'readiness to take part in the liturgical life of the church and to make use of the rights of passage', suggesting (as was implied above) that baptism or initiation into the life of the church is a crucial element in one's crossing the threshold of divine revelation. 
Earlier we noted that at times Abraham appears to suggest that Christian initiation is inextricably linked to initiation into a real ecclesial community. It is likely that this understanding of initiation is behind Abraham's contention that the indifferent churchgoer has crossed the threshold of divine revelation, while the earnest seeker (MC) who has not been initiated into church but has engaged in a real spiritual journey has not crossed the threshold of divine revelation. Thus it seems that, for Abraham, one cannot cross the threshold of divine revelation and remain a nonmember of the church. This indicates that the indifferent church member's advantage over and above MC is simply that the indifferent church member, having been baptised, has access to the means of grace supplied within the church, whereas MC does not. This suggests that, for Abraham, revelation is primarily available within these means and not outside of them.

Thus far we have tried to see whether Abraham provides a thorough account of the appropriation of revelation outside that of the canonical heritage of the church and have found that he does not. We have been left with several unanswered questions: What are Abraham's assumptions about creation and the universal operation of prevenient grace? How are the appropriate cognitive conditions (purity of heart) for perceiving God attained? What is it to cross the threshold of divine revelation? Clearly these questions need answering if Abraham is to provide a full account of an individual's appropriation of divine revelation. If canonical theism is justified by the reasons that ordinary believers have for their commitment to canonical theism, then Abraham needs to clearly show how such ordinary believers come to believe in canonical theism. Although Abraham appeals to the way in which the canonical heritage is used in leading people to believe in canonical theism, this does not really accomplish the task in hand, for if the warrant people have for being committed to canonical theism is the canons of the church (which constitute canonical theism) then Abraham's account is circular. Abraham thus needs to provide a thorough account of the appropriation of divine revelation outside of the use of the canonical materials. This he does not do.

\section{Conclusion}

In exploring Abraham's account of the epistemology of canonical theism two key concerns have been raised. First of all, if the church is a vessel for divine revelation, if revelation is mediated through the church and thus received through initiation into a concrete physical community, which church upholds canonical theism today ${ }^{45}$ Secondly, if canonical theism is defended through an appeal to divine revelation, and if individuals become committed to canonical theism by revelation as mediated through the church's canons, then belief in canonical theism is supported by canonical theism. Nevertheless, while identifying these difficulties, we have also argued that if Abraham can provide a more thorough account of the way in which individuals come to receive revelation aside from their reception of the canonical heritage, then his proposal could avoid these difficulties. Of late Abraham has begun to explore the concept of revelation in a number of significant Christian thinkers (2017c). This suggests that he believes a more robust account of the appropriation of revelation can be found within the riches of the wider Christian tradition. While these ideas remain undeveloped Abraham declares that 'I seek in time to articulate ... a rich vision of divine action that runs from conversion back to creation and forward to the eschaton' (2017b:14). If the insights from his analysis of all of these approaches were put together he could provide a robust account of the appropriation of revelation suitable to the task of closing the gaps identified in his proposal. The criticisms made above are offered constructively so as to assist the realisation of this important vision for Christian renewal. ${ }^{46}$

\section{Acknowledgements Competing interests}

The author declares that he has no financial or personal relationships which may have inappropriately influenced him in writing this article.

\section{References}

Abraham, W.J., 1981, The divine inspiration of holy scripture, University Press, Oxford.

Abraham, W.J., 1982, Divine revelation and the limits of historical criticism, University Press, Oxford.

Abraham, W.J., 1984, The coming great revival: Recovering the full evangelical tradition, Harper \& Row, San Francisco, CA.

Abraham, W.J., 1995, Waking from doctrinal amnesia: The healing of doctrine in the United Methodist Church, Abingdon Press, Nashville, TN.

Abraham, W.J., 1998, Canon and criterion in Christian theology, Clarendon Press, Oxford.

Abraham, W.J., 2001, 'I can see people but they look like trees walking. A response to professor Webster', Scottish Journal of Theology 54(1), 238-243. https://doi. org/10.1017/S003693060005136X

Abraham, W.J., 2002, The logic of evangelism, Eerdmans, Grand Rapids, MI.

Abraham, W.J., 2003, 'Saving souls in the twenty-First century: A missiological midrash On John Wesley', Wesleyan Theological Journal 38(1), 7-21.

Abraham, W.J., 2003b, The logic of renewal, SPCK, London.

Abraham, W.J., 2005a, 'The end of Wesleyan theology,' Wesleyan Theological Journal 40(1), 7-25.

Abraham, W.J., 2005b, Wesley for Armchair theologians, John Knox Press, Louisville, KY. Abraham, W.J., 2006, Crossing the threshold of divine revelation, Eerdmans, Grand Rapids, MI.

Abraham, W.J., 2008, Canonical theism, Eerdmans, Grand Rapids, MI.

Abraham, W.J., 2009, 'Systematic theology as analytic theology,' in O. Crisp \& M. Rea (eds.), Analytic Theology: New essays in the philosophy of theology, pp.54-69, University Press, Oxford.

Abraham, W.J., 2010, 'Church', in C. Taliaferro \& C. Meister (eds.), The Cambridge companion to Christian philosophical theology, pp. 170-182, University Press, Cambridge.

Abraham, W.J., 2010b, 'Philosophical reflection on revelation and scripture', in P. Quinn \& C. Taliaferro (eds.), A companion to philosophy of religion, pp. 695-701, Blackwell, Oxford.

Abraham, W.J., 2017b, Divine agency and divine action: Volume I, University Press, Oxford.

Abraham, W.J., 2017c, Divine agency and divine action: Volume II, University Press, Oxford

Abraham, W. \& Aquino, F., 2017, 'Introduction', in W. Abraham \& F. Aquino (eds.), The oxford handbook of the epistemology of theology, pp. 1-8, University Press, Oxford.

Alston, W.P., 1991, Perceiving God, Cornell University Press, Ithaca, NY.

46. I would like to thank Ooliver Crisp for his comments on the first draft of this essay (the mistakes remain my own) and for his introducing me to Abraham's work (the mistakes remain my own) and for his introducing me to Abraham's work
(2008). I would also like to thank Graham Duncan, Mike Brealey and Paul Tiffin for their encouragement along the way. 
Alston, W.P., 1993, The reliability of sense perception, Cornell University Press, Ithaca, NY. Aristotle, 2000, Nicomachean ethics, trans. Roger Crisp. University Press, Cambridge. Buckareff, A.A., 2009, 'Notes and comments: Metaepistemology and divine revelation', The HeythropJournal50(1),85-90.https://doi.org/10.1111/j.1468-2265.2008.00407.x

Chisholm, R.M., 1973, The problem of the criterion, Marquette University Press, Milwaukee, WI.

Fiorenza, F.S., 2002, 'A Roman Catholic Perspective on the Offense of Revelation: Response to William Abraham,' The Harvard Theological Review 95(3), 265-271. Response to William Abraham,' The Harvard The
https://doi.org/10.1017/S0017816002000172

Ford, J., 2006, 'Crossing the threshold of divine revelation by William Abraham', Religious Studies 32(3), 184. https://doi.org/10.1111/j.1748-0922.2006.00088_36.x

Fout, J.A., 2008, 'Crossing the threshold of divine revelation by William Abraham', Reviews in Religion and Theology 15(3), 392-395. https://doi.org/10.1111/j.14679418.2008.00391_2.x

Grenz, S., 2001, 'Deconstructing epistemological certainty: An engagement with William Abraham', Wesleyan Theological Journal 36(1), 37-45.

Hick, J., 1966, Faith and knowledge, Cornell University Press, Ithaca, NY.

Hick, J., 1989, The interpretation of religion, Yale University Press, New Haven, CT.

Lamberth, D., 2002, 'Discernment and practice: Questions for a logic of revelation: Response to William Abraham', The Harvard Theological Review 95(3), 273-276. https://doi.org/10.1017/S0017816002000184

Levering, M., 2007, 'William Abraham and St. Thomas Aquinas', New Blackfriars 88(1013), 46-55. https://doi.org/10.1111/j.1741-2005.2006.00128.x

Lindbeck, G.A., 1999, 'Canon and criterion in Christian theology by William Abraham', First Things 10(4), 68.

Long, S., 2003, 'Response to Abraham', Ex Audito 19(1), 65-75.

MacSwain, R., 2008, 'Crossing the threshold of divine revelation by William Abraham', International Journal of Systematic Theology 10(2), 219-222. https://doi. International Journal of Systematic
org/10.1111/j.1468-2400.2008.00321.x

Neve, D.A., 2010, 'Unpublished PhD Thesis', Southern Methodist University, Dallas, TX.

Newman, J.H., 1845, An essay on the development of Christian Doctrine, James Toovey, London.

Newman, J.H., 1859a, 'Judgement of the English Bishops on the Royal Commission' The Rambler 1(1), 117-123.

Newman, J.H., 1859b, 'On consulting the faithful in matters of Doctrine', The Rambler $1(2), 198-230$.
Phillips, D.Z., 1981, The concept of prayer, Seabury Press, NY.

Phillips, D.Z., 1988, Faith after foundationalism, Routledge, London.

Plantinga, A., 2000, Warranted Christian Belief, University Press, Oxford.

Pratt Morris-Chapman, D.J., 2010, Whither Methodist theology now, Methodist Sacramental Fellowship, Tiverton.

Pratt Morris-Chapman, D.J., 2016, 'Newman and the problem of the criterion revisited', Newman Studies Journal 13(1), 55-67.

Smith, P.T., 2007, 'Crossing the threshold of divine revelation by William Abraham', Christian Scholar's Review 36(3), 137-141.

Smith, J.K., 2008, 'Epistemology for the rest of Us Hints of a Paradigm Shift in Abraham's Crossing the Threshold', Philosophia Christi 10(2), 353-361.

Sosa, E., 1991, Knowledge in perspective: Selected essays in epistemology, University Press, Cambridge.

Swinburne, R., 1991, The existence of God, Clarendon, Oxford.

Treier, D.J., 2008, 'A looser "Canon"? Relating William Abraham's "Canon and criterion in Christian Theology" to biblical interpretation', Journal of Theological Interpretation 2(1), 101-116.

Vidu, A., 2009, 'Crossing the threshold of divine revelation by William J. Abraham', Heythrop Journal 50(1), 134-135. https://doi.org/10.1111/j.1468-2265.2009.00438_16.x

Wainwright, W.J., 1995, Reason and the Heart: A prolegomenon to a critique of passional reason, Cornell University Press, Ithaca, NY.

Watt, G.D., 2012, 'Methodist ecclesiology and identity in Great Britain: A pragmatic Trinitarian ecclesiology in the midst of competing views of God', Unpublished PhD Thesis, University of Bristol, UK.

Webster, J., 2001, 'Article review: Canon and criterion: Some reflections on a recent proposal,' Scottish Journal of Theology 54(1), 221-237. https://doi.org/10.1017/ S0036930600051358

Wolterstorff, N., 1995, Divine discourse: Philosophical reflections on the claim that God speaks, University Press, Cambridge.

Wolterstorff, N., 2011, 'Crossing the Threshold of Divine Revelation by William J. Abraham,' Faith and Philosophy 28(1), 102-108. https://doi.org/10.5840/ faithphil201128120

Work, T., 2002, Living and active: Scripture in the economy of salvation, Eerdmans, Grand Rapids, MI.

Yandell, P., 1993, The epistemology of religious experience, University Press, Cambridge. 